UDC: $579.846 .2: 22$

\title{
DISSIMILATORY SULFITE REDUCTASE IN CELL-FREE EXTRACTS OF INTESTINAL SULFATE-REDUCING BACTERIA
}

\author{
Ivan V. Kushkevych ${ }^{1,2}$, Roman V. Fafula ${ }^{3}$ \\ ${ }^{1}$ Institute of Animal Biology of NAAS of Ukraine, 38, V. Stus St., Lviv 79034, Ukraine \\ ${ }^{2}$ University of Veterinary and Pharmaceutical Sciences Brno \\ 1/3, Palackeho, CZ-61242 Brno, Czech Republic \\ e-mail: ivan.kushkevych@gmail.com \\ ${ }^{3}$ Danylo Halytsky Lviv National Medical University, 69, Pekarska St., Lviv 79010, Ukraine
}

\begin{abstract}
Dissimilatory sulfite reductase activity in different fractions of the sulfate-reducing bacteria Desulfovibrio piger Vib-7 and Desulfomicrobium sp. Rod-9 isolated from human intestine was studied. Sulfite reductase, an important enzyme in the process of sulfur metabolism in these bacteria, was solubilized from the membrane fraction. The highest activity of the enzyme in the cell-free extract of the bacterial strains was measured $\left(0.032 \pm 0.0026\right.$ and $0.028 \pm 0.0022 \mathrm{U} \times \mathrm{mg}^{-1}$ protein for D. piger Vib-7 and Desulfomicrobium sp. Rod-9, respectively) compared to other fractions. The optimal temperature $\left(+30 \ldots 35^{\circ} \mathrm{C}\right)$ and $\mathrm{pH} 7.0$ for sulfite reductase reaction in the extracts of both bacterial strains was determined. The spectral analysis of purified sulfite reductase from cellfree extracts was carried out. The absorption maxima were 284, 391, 412, 583, and $630 \mathrm{~nm}$, as well as $287,393,545$, and $581 \mathrm{~nm}$ for sulfite reductase of $D$. piger Vib-7 and Desulfomicrobium sp. Rod-9, respectively. Analysis of the kinetic properties of the bacterial sulfite reductase has been carried out. The sulfite reductase activity, initial (instantaneous) reaction rate $\left(V_{0}\right)$ and maximum rate of the sulfite reductase reaction $\left(V_{\max }\right)$ were higher in the $D$. piger Vib-7 cells than in the Desulfomicrobium sp. Rod-9. However, Michaelis constants $\left(K_{m}\right)$ of the enzyme activity were similar for both bacterial strains. The studies of the sulfite reductase activity, the kinetic properties of this enzyme in the intestinal sulfate-reducing bacteria strains, and their production of hydrogen sulfide in detail can be useful for clarification of the etiological role of these bacteria in the development of inflammatory bowel diseases in humans and animals.
\end{abstract}

Keywords: sulfate-reducing bacteria, sulfite reductase, intestinal microbiocenosis, inflammatory bowel diseases, ulcerative colitis.

\section{INTRODUCTION}

Sulfate-reducing bacteria occur in the gut flora of about $50 \%$ of healthy persons where they metabolize hydrogen and low molecular weight organic compounds [4]. High concentration of sulfate in gut creates favorable conditions for the development of the sulfate-reducing bacteria in the human and animal intestine [2, 3]. These conditions are also favorable for process of the dissimilatory sulfate reduction and accumulation of 
hydrogen sulfide and acetate which can be cytotoxic to intestinal cells causing various inflammatory bowel diseases. Hydrogen sulfide accumulated in the human intestine is also carcinogenic to its cells and can cause inhibition of cytochrome oxidase, oxidation processes butyrate by colonocytes, and destruction of epithelial cells, develop ulcers, inflammation with subsequent development of colon cancer [2, 10]. The production of highly toxic sulfide from Desulfovibrio desulfuricans has been implicated in the onset of a chronic inflammatory large bowel disease, ulcerative colitis, patients with this disease showing elevated levels of sulfide production and a universal carriage rate of the sulfatereducing bacteria $[3,4]$.

The process of the dissimilatory sulfate reduction to sulfide occurs due to the formation of many intermediate compounds. One of these intermediates is sulfite, the reduction of which to sulfide is an intermediary step of sulfate reduction in sulfate assimilating organisms $[6,9]$. Sulfite reduction is also a terminal step of sulfate reduction and a possible energy-yielding reaction in sulfate-reducing bacteria [7].

Sulfite reductase catalyses the reduction of sulfite to sulfide and forms part of the dissimilatory sulfate reduction pathway $[6,7]$. The enzyme from the sulfate-reducing bacteria of the Desulfovibrio genus is a hexamer consisting of three different subunits $[6,16,19,20]$. Contrary to the case of sulfite reduction in sulfate assimilation, Kobayashi et al. have suggested from fractionation experiments that in extracts of Desulfovibrio vulgaris sulfite is reduced stepwise to sulfide with intermediary formation of trithionate and thiosulfate [7]. Sulfite reductase, which reacts directly with sulfite in a series of reduction steps from sulfite to sulfide, was purified from $D$. vulgaris and the identity of the enzyme was suggested with a green pigment, desulfoviridin $[7,18]$. The demonstration by Lee and Peck (1973) that desulfoviridin is the enzyme responsible for the reduction of sulfite to trithionate raised the problem of the mechanism of sulfite reduction in the Norway strain of $D$. desulfuricans $[13,14]$. In this investigation, was reported the purification of a red pigment, which has been provisionally termed desulforubidin, from this anomalous strain of $D$. desulfuricans, and its identification as an enzyme that reduces sulfite mainly to trithionate, analogous to desulfoviridin $[6,7]$.

As far as it is aware, sulfite reductase from intestinal sulfate-reducing bacteria D. piger and Desulfomicrobium has never been well-characterized. From literature data, there are a lot of data about sulfite reductase of the sulfate-reducing bacteria isolated from environment $[6,7,14,16,17,19,20]$. However, the data about activity of this enzyme from intestinal sulfate-reducing bacteria Desulfovibrio piger and Desulfomicrobium $\mathrm{sp}$. has not been reported yet.

The aim of our work was to study sulfite reductase activity of sulfate-reducing bacteria $D$. piger Vib-7 and Desulfomicrobium sp. Rod-9 isolated from the human large intestine and to carry out the kinetic analysis of enzymatic reaction.

\section{MATERIALS AND METHODS}

Objects of the study were sulfate-reducing bacteria Desulfovibrio piger Vib-7 and Desulfomicrobium sp. Rod-9 isolated from the human large intestine [11] and identified by the sequence analysis of the 16S rRNA gene [12]. The strains are kept in the collection of microorganisms at the Laboratory of Biotechnology, Faculty of Pharmacy, University of Veterinary and Pharmaceutical Sciences Brno (Czech Republic).

Bacterial growth and cultivation. Bacteria were grown in a nutrition-modified Kravtsov-Sorokin's liquid medium with the following composition $(\mathrm{g} / \mathrm{l})$ : $\mathrm{Na}_{2} \mathrm{SO}_{4}-0.5 ; \mathrm{KH}_{2} \mathrm{PO}_{4}$ 0.3; $\mathrm{K}_{2} \mathrm{HPO}_{4}-0.5 ;\left(\mathrm{NH}_{4}\right)_{2} \mathrm{SO}_{4}-0.2 ; \mathrm{NH}_{4} \mathrm{Cl}-1.0 ; \mathrm{CaCl}_{2} \times 6 \mathrm{H}_{2} \mathrm{O}-0.06 ; \mathrm{MgSO}_{4} \times 7 \mathrm{H}_{2} \mathrm{O}-0.1$; 
$\mathrm{C}_{3} \mathrm{H}_{5} \mathrm{O}_{3} \mathrm{Na}-2.0$; yeast extract - 1.0; $\mathrm{FeSO}_{4} \times 7 \mathrm{H}_{2} \mathrm{O}-0.004$; and sodium citrate $\times 2 \mathrm{H}_{2} \mathrm{O}-$ 0.3 . Before bacteria seeding in the medium, $0.05 \mathrm{ml} / \mathrm{l}$ of sterile solution of $\mathrm{Na}_{2} \mathrm{~S} \times 9 \mathrm{H}_{2} \mathrm{O}$ (1\%) was added. A sterile $10 \mathrm{~N}$ solution of $\mathrm{NaOH}(0.9 \mathrm{ml} / \mathrm{l})$ in the medium was used to provide the final $\mathrm{pH} 7.2$. The medium was heated in boiling water for $30 \mathrm{~min}$ in order to obtain an oxygen-free medium, and then cooled to $+30^{\circ} \mathrm{C}$. The bacteria were grown for 72 hours at $+37^{\circ} \mathrm{C}$ under anaerobic conditions. The tubes were brim-filled with medium and closed to provide anaerobic conditions.

Obtaining cell-free extracts. Cell-free extracts were prepared from stationary-phase cultures. The cold extraction buffer (50 mM potassium phosphate buffer, $\mathrm{pH} 7.5,10^{-5} \mathrm{M}$ EDTA (ethylenediaminetetraacetic acid) was added to centrifuged cells to bind heavy metal ions. A total of $10^{-5} \mathrm{M}$ PMSF (phenylmethylsulfonyl fluoride) for the inhibition of proteases, which is effective at $\mathrm{pH}$ above 7.0, was added. After this procedure, a suspension of cells $(150-200 \mathrm{mg} / \mathrm{ml})$ was obtained. The cells were homogenized using the ultrasonic disintegrator at $22 \mathrm{kHz}$ for 5 minutes at $0{ }^{\circ} \mathrm{C}$ to obtain cell-free extracts. The suspension was displaced into centrifugal tubes and separated from the cells fragments by centrifugation in 30 minutes at $15000 \mathrm{rpm}$ and at $+4{ }^{\circ} \mathrm{C}$. The supernatant was used as cell-free extract. Soluble fraction was prepared as described in paper [18]. The spinned cells fragments were used as sedimentary fraction. Protein concentration in the cell-free extracts was determined by the Lowry method [15].

Assays for sulfite reductase activity, desulfoviridin, and desulforubidin. The sulfite reductase activity was assayed manometrically by measuring hydrogen uptake required for sulfite reduction coupled with the hydrogenace methylviologen system. Purification of the enzyme and its spectral analysis were carried out as described in paper [6]. Hydrogen uptake was measured for 5 to $100 \mathrm{~min}$. One unit of enzyme was defined as an amount which consumed $1 \mu$ mole of hydrogen per min in the initial phase of the reaction. Enzyme activity was expressed as $\mathrm{U}_{\times \mathrm{mg}^{-1}}$ protein. Reaction products (thiosulfate, trithionate, and polythionate containing four or more sulfur atoms) were determined colorimetrically by a modification of the methods described in paper [6, 7]. Desulfoviridin and desulforubidin were measured spectrophotometrically as described in paper [6, 13]. The activity of the studied enzyme in the cell-free extracts of both bacterial strains under the effect of different temperature $\left(+20,+25,+30,+35,+40,+45^{\circ} \mathrm{C}\right)$ and $\mathrm{pH}(4.0,4.5,5.0$, $5.5,6.0,6.5,7.0,7.5,8.0,8.5,9.0,9.5,10.0)$ in the medium incubation was measured.

Kinetic analysis. Kinetic analysis of the enzyme reaction was performed in a standard incubation medium [6] with modified physical and chemical characteristics of the respective parameters (the incubation time, substrate concentration, temperature and $\mathrm{pH})$. The kinetic parameters characterizing the sulfite reductase reaction are the initial (instantaneous) reaction rate $\left(V_{0}\right)$, maximum rate of the reaction $\left(V_{\max }\right)$, maximum amount of the reaction product $\left(P_{\max }\right)$ and characteristic reaction time (time half saturation) $\tau$ were determined [8]. The amount of the reaction product was calculated stoichiometrically. The kinetic parameters characterizing sulfite reductase reactions are Michaelis constant $\left(K_{m}\right)$ and maximum reaction rate of substrate decomposition were determined by Lineweaver-Burk plot [5].

Statistical analysis. Kinetic and statistical calculations of the results were carried out using the software MS Office and Origin computer programs. The research results were calculated by the methods of variation statistics using Student $t$-test. The absolute value of the correlation coefficient $r$ was from 0.90 to 0.99 . The significance of the calculated parameters of samples was tested by the Fisher's F-test. The accurate approximation was when $\mathrm{P} \leq 0.05$ [1].

ISSN 1996-4536 (print) • ISSN 2311-0783 (on-line) • Біологічні Студії / Studia Biologica • 2014 • Том 8/№2 • C. 101-112 


\section{RESULTS AND DISCUSSION}

Sulfite reductase, an important enzyme in the process of sulfur metabolism in sulfate-reducing bacteria, was obtained from cells of $D$. piger Vib-7 and Desulfomicrobium sp. Rod-9. Activity of sulfite reductase in different fractions including cell-free extract, soluble, and sedimentary was studied (Table 1).

Table 1. Sulfite reductase activity in different fractions obtained from Desulfovibrio piger Vib-7 and Desulfomicrobium sp. Rod-9 cells

Таблиця 1. Активність сульфітредуктази у різних фракціях, отриманих з клітин Desulfovibrio piger Vib-7 i Desulfomicrobium sp. Rod-9

\begin{tabular}{|c|c|c|c|c|}
\hline \multirow{3}{*}{ Sulfate-reducing bacteria } & \multicolumn{3}{|c|}{$\begin{array}{l}\text { Specific activity of sulfite reductase } \\
\left(\mathrm{U} \times \mathrm{mg}^{-1} \text { protein }\right)\end{array}$} & \multirow{3}{*}{$\begin{array}{l}\text { Desulfoviridin/ } \\
\text { *Desulforubidir } \\
\text { (Units) }\end{array}$} \\
\hline & \multirow{2}{*}{$\begin{array}{c}\text { Cell-free } \\
\text { extract }\end{array}$} & \multicolumn{2}{|c|}{ Individual fractions } & \\
\hline & & Soluble & Sedimentary & \\
\hline Desulfovibrio piger Vib-7 & $0.032 \pm 0.0026$ & $0.029 \pm 0.0021$ & $0.0012 \pm 0.0002$ & $109 \pm 9.71$ \\
\hline Desulfomicrobium sp. Rod-9 & $0.028 \pm 0.0022$ & $0.024 \pm 0.0018$ & $0.0010 \pm 0.0001$ & *102 \pm 8.96 \\
\hline
\end{tabular}

Comment: Enzyme activity has been determined after 100 min incubation. Significance of the values $M \pm m$, $n=5$.

Примітка: Активність ферменту визначена після 100 хв інкубації. Достовірність значень $\mathrm{M} \pm \mathrm{m}, \mathrm{n}=5$.

Results of this study showed that the highest specific activity of the enzyme was measured in cell-free extracts $\left(0.032 \pm 0.0026\right.$ and $0.028 \pm 0.0022 \mathrm{U} \times \mathrm{mg}^{-1}$ protein for D. piger Vib-7 and Desulfomicrobium sp. Rod-9, respectively). Slightly lower activity of sulfite reductase was detected in the soluble fraction compared to cell-free extracts. The lowest enyzme activity was found in sedimentary fraction; its values designated

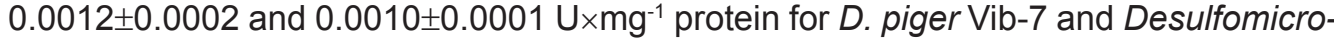
bium sp. Rod-9, respectively. The level of desulfoviridin and desulforubidin was almost the same in both bacterial strains.

From literature data, it is known that the enzyme activity depends on temperature and $\mathrm{pH}[2,7]$. The effect of temperature and $\mathrm{pH}$ of the incubation medium on the sulfite reductase activity in the cell-free extracts of the sulfate-reducing bacteria was studied (Fig. 1). The maximum specific activity for both bacterial strains was determined at $+30 \ldots 35^{\circ} \mathrm{C}$. An increase or decrease in temperature of incubation leads to a decrease of the activity of studied enzyme in the cell-free bacterial extracts. The highest enzyme activity of sulfite reductase was determined in the cell-free extracts of the D. piger Vib-7 and the Desulfomicrobium sp. Rod-9 at pH 7.0.

Thus, temperature and $\mathrm{pH}$ optimum of this enzyme with sulfite as a substrate was $+30 \ldots 35^{\circ} \mathrm{C}$ and $\mathrm{pH} 7.0$, respectively. The enzyme activity exhibited typical bell-shaped curves as a function of temperature and $\mathrm{pH}$.

Reaction products (thiosulfate, trithionate, and polythionate containing four sulfur atoms) in the cell-free extracts of Desulfovibrio piger Vib-7 and Desulfomicrobium sp. Rod-9 were determined. As shown in Table 2, the highest concentration trithionate, $0.54 \pm 0.044$ and $0.49 \pm 0.037 \mu$ moles, was measured in the cell-free extracts of $D$. piger Vib-7 and Desulfomicrobium sp. Rod-9, respectively.

Accumulation of the final product of the sulfate-reducing bacteria metabolism was $0.47 \pm 0.035 \mu$ moles for extracts of $D$. piger Vib-7 and $0.36 \pm 0.029 \mu$ moles for Desulfomic-

ISSN 1996-4536 (print) • ISSN 2311-0783 (on-line) • Біологічні Студії / Studia Biologica • 2014 • Том 8/№2 • C. 101-112 
robium sp. Rod-9. The lowest concentration of intermediates was observed for polythionate, its values designated $0.018 \pm 0.0014$ and $0.012 \pm 0.0011 \mu$ moles for $D$. piger Vib-7 and Desulfomicrobium sp. Rod-9, respectively. Perhaps, trithionate plays an important role in the metabolism of the studied intestinal bacteria among other intermediates. The detection of trithionate and thiosulfate as intermediate compounds during the dissimilatory sulfite reduction process by Desulfovibrio vulgaris was first reported by Kobayashi et al. [6]. Subsequently, thiosulfate was shown to accumulate in reaction mixtures containing two fractions isolated from $D$. vulgaris extracts [7].
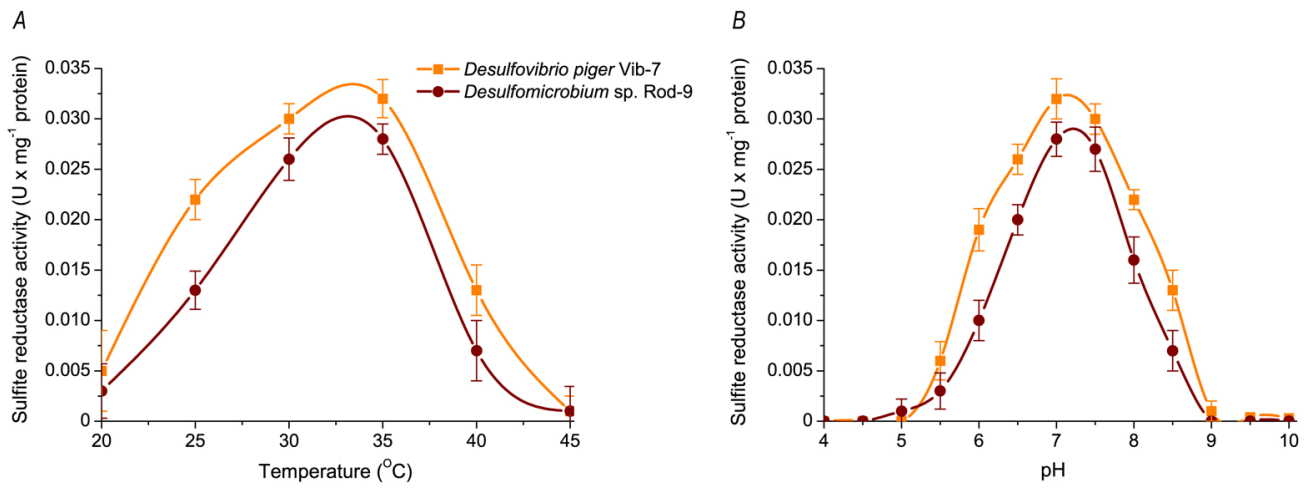

Fig. 1. Effect of temperature $(A)$ and $\mathrm{pH}(B)$ on the activity of sulfite reductase in cell-free extracts of $D$. piger Vib-7 and Desulfomicrobium sp. Rod-9

Рис. 1. Вплив температури $(A)$ і рH $(B)$ на активність сульфітредуктази у безклітинних екстрактах $D$. piger Vib-7 i Desulfomicrobium sp. Rod-9

Table 2. Sulfite reduction and formation of products reaction in the cell-free extracts of Desulfovibrio piger Vib-7 and Desulfomicrobium sp. Rod-9 stains

Таблиця 2. Відновлення сульфіду та утворення продуктів реакції у безклітинних екстрактах штамів Desulfovibrio piger Vib-7 і Desulfomicrobium sp. Rod-9

\begin{tabular}{|l|c|c|c|c|c|}
\hline & \multicolumn{5}{|c}{ Formed compounds $(\mu$ moles) } \\
\cline { 2 - 7 } Sulfate-reducing bacteria & $\mathrm{S}_{2} \mathrm{O}_{3}^{2-}$ & $\mathrm{S}_{3} \mathrm{O}_{6}^{2-}$ & $\mathrm{S}_{4} \mathrm{O}_{6}^{2-}$ & $\mathrm{H}_{2} \mathrm{~S}$ & $\begin{array}{c}\text { Total sulfite } \\
\text { recovered }\end{array}$ \\
\hline Desulfovibrio piger Vib-7 & $0.21 \pm 0.017$ & $0.54 \pm 0.044$ & $0.018 \pm 0.0014$ & $0.47 \pm 0.035$ & $1.24 \pm 0.119$ \\
\hline Desulfomicrobium sp. Rod-9 & $0.25 \pm 0.019$ & $0.49 \pm 0.037$ & $0.012 \pm 0.0011$ & $0.36 \pm 0.029$ & $1.11 \pm 0.107$
\end{tabular}

Comment: $5 \mu$ moles $\mathrm{Na}_{2} \mathrm{SO}_{3}$ in incubation mixture was added. The formed products were determined at $+35^{\circ} \mathrm{C}$ and $\mathrm{pH} 7.0$ after 100 min reaction. Significance of the values $\mathrm{M} \pm \mathrm{m}, \mathrm{n}=3$.

Примітка: 5 мкмоль $\mathrm{Na}_{2} \mathrm{SO}_{3}$ було внесено до інкубаційної суміші. Утворені продукти визначали за температури $+35^{\circ} \mathrm{C}$ і рН 7,0 після 100 хв реакції. Достовірність значень $\mathrm{M} \pm \mathrm{m}, \mathrm{n}=3$.

Next task of this study was to carry out a spectral analysis of the purified sulfite reductase from the cell-free extracts of $D$. piger Vib-7 and Desulfomicrobium sp. Rod-9. The absorption maxima were $284,391,412,583$, and $630 \mathrm{~nm}$ as well as $287,393,545$, and $581 \mathrm{~nm}$ for sulfite reductase of $D$. piger and Desulfomicrobium sp. Rod-9, respectively (Fig. 2, A). From literature data, it is known that the visible region of these spectra is quite similar to that of the pigments, desulfoviridin and desulforubidin $[6,13,18]$. Ffluorescence spectrum of desulfoviridin in $0.1 \mathrm{~N} \mathrm{NaOH}$ excited at $365 \mathrm{~nm}$, and absorption 
spectrum of desulforubidin $(2.47 \mathrm{mg} / \mathrm{ml})$ with $0.2 \mathrm{~N} \mathrm{NaOH}$, the absorption maxima at 393 and $547 \mathrm{~nm}$ were demonstrated (Fig. 2, B). The ratio of optical density at 284, 412, and 630 as well as 396, 557, and 581 were about $6: 3: 1$. Addition of alkali or acid caused bleaching of the greenish colour of desulfoviridin and reddish brown color of desulforubidin as well as shifted the absorption peaks toward short wavelengths. The red fluorescence under UV light was quite unstable. The enzyme protein (desulfoviridin) showed a strong red fluorescence with an emission maximum at $600 \mathrm{~nm}$ in alkali or $1 \%$ SDS solution when excited at $365 \mathrm{~nm}$ (Fig. 2).

A

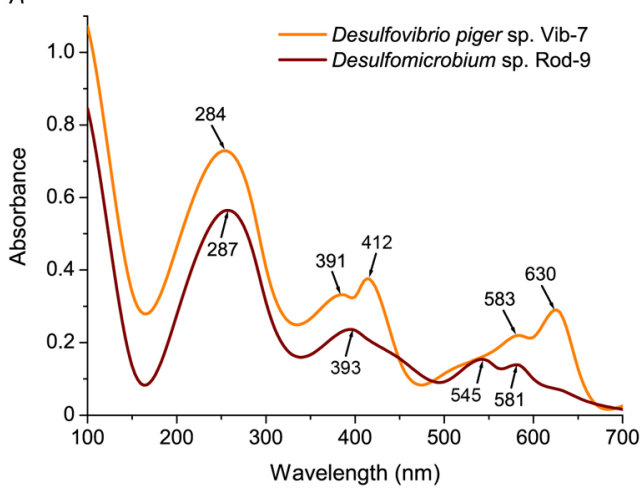

$B$

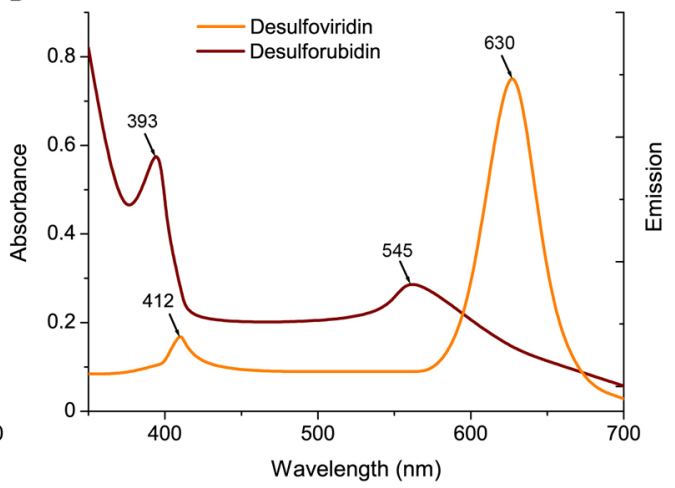

Fig. 2. Absorption spectra of sulfite reductase from D. piger Vib-7 and Desulfomicrobium sp. Rod-9. Protein concentration was $3.18 \mathrm{mg}$ (for D. piger Vib-7) and $2.84 \mathrm{mg}$ (for Desulfomicrobium sp. Rod-9) based on Lowry's method per ml of $0.01 \mathrm{M}$ Tris buffer, $\mathrm{pH} 7.0(A)$. Ffluorescence spectrum of desulfoviridin in $0.1 \mathrm{~N} \mathrm{NaOH}$ excited at $365 \mathrm{~nm}$, and absorption spectrum of desulforubidin $(2.47 \mathrm{mg} / \mathrm{ml})$ in $0.2 \mathrm{~N}$ $\mathrm{NaOH}$, the absorption maxima at 396 and $557 \mathrm{~nm}(B)$

Рис. 2. Спектри поглинання сульфітної редуктази D. piger Vib-7 і Desulfomicrobium sp. Rod-9. Концентрація білка 3,18 мг (для D. piger Vib-7) і 2,84 мг (для Desulfomicrobium sp. Rod-9) визначена методом Лоурі на мл 0,01 М Тріс-буфера, pH 7,0 (A). Спектр флуоресценції десульфовіридину у 0,1 N NaOH при 365 нм та спектр поглинання десульфорубідину (2,47 мг/мл) у 0,2 N NaOH, максимуми поглинання при 396 і 557 нм (B)

Kobayashi et al. (1972) obtained the similar data for Desulfovibrio vulgaris sulfite reductase. The absorption spectrum of the purified enzyme preparation had absorption maxima at $630,585,410,390$, and $280 \mathrm{~nm}$ and a shoulder at $290 \mathrm{~nm}$. The ratio of optical density at 630,410 , and $280 \mathrm{~nm}$ was similar to our obtained results, it was about $1: 3: 6$. The authors have also shown that the enzyme protein had a strong red fluorescence with an emission maximum at $600 \mathrm{~nm}$ in alkali solution [6].

A new pigment, purified from extracts of the Norway strain of Desulfovibrio desulfuricans, desulforubidin, that has sulfite reducing activity, has been described by Lee et al. The authors registered absorption spectra maxima of desulforubidin at 392, 545, and $580 \mathrm{~nm}[13]$.

To study the characteristics and mechanism of sulfite reductase reaction, the initial (instantaneous) reaction rate $\left(V_{0}\right)$, maximum rate of the reaction $\left(V_{\max }\right)$, maximum amount of reaction product $\left(P_{\max }\right)$ and reaction time $(\tau)$ were defined. Dynamics of hydrogen uptake in the cell-free extracts of $D$. piger Vib-7 and Desulfomicrobium sp. Rod-9 was studied for investigation of the kinetic parameters of sulfite reductase (Fig. 3). 
Experimental data showed that the kinetic curves of sulfite reductase activity have tendency to saturation (Fig. 3, A). Analysis of the results allows to reach the conclusion that the kinetics of sulfite reductase activity in cell-free extracts of the sulfate-reducing bacteria was consistent to the zero-order reaction in the range of 0-10 min (the graph of the dependence of product formation on the incubation time was almost linear in this interval of time). Therefore the duration of the incubation of bacterial cells extracts was $15 \mathrm{~min}$ in subsequent experiments.

A
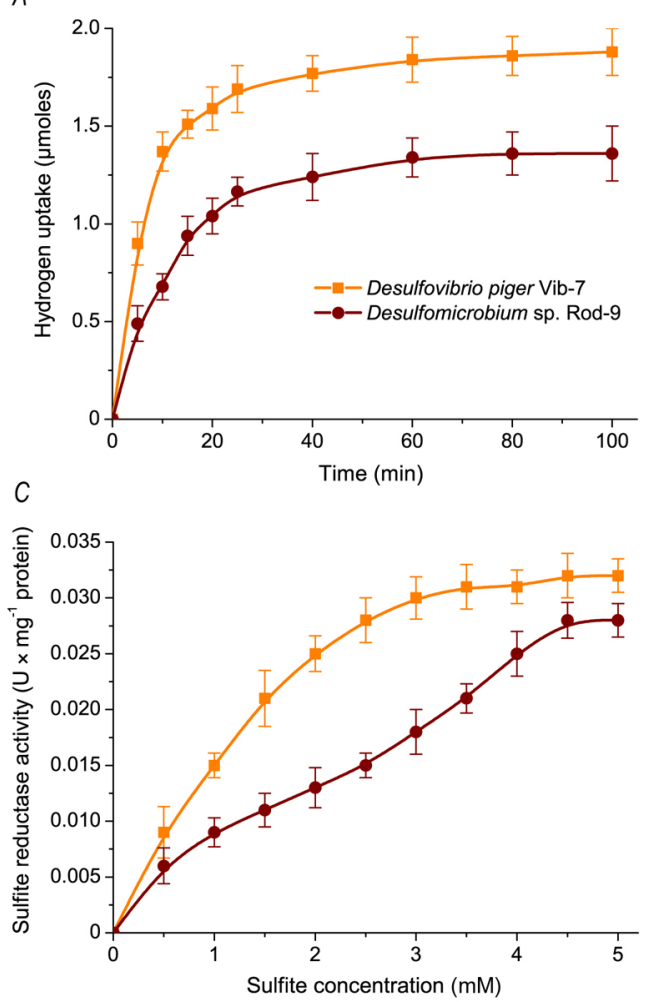

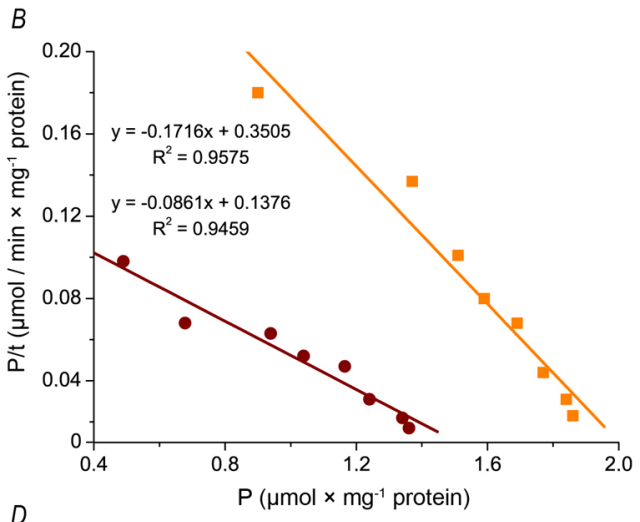

$D$

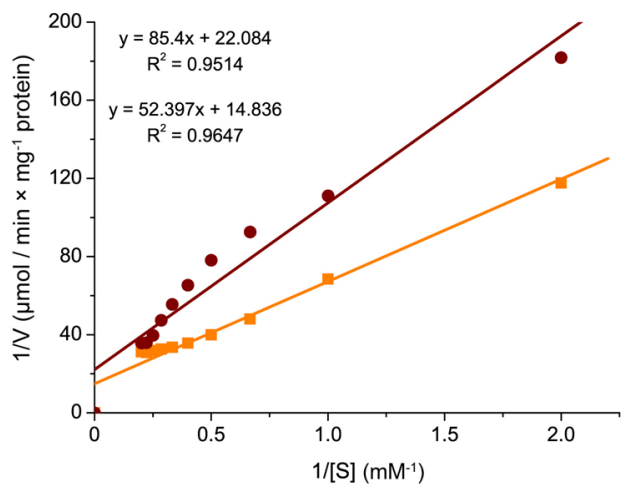

Fig. 3. Kinetic parameters of sulfite reductase activity in cell-free extracts of $D$. piger Vib-7 and Desulfomicrobium sp. Rod-9: $\boldsymbol{A}$ - dynamics of product accumulation ( $\mathrm{M} \pm \mathrm{m}, \mathrm{n}=5$ ); $\boldsymbol{B}$ - linearization of curves of product accumulation in $\{\mathrm{P} / \mathrm{t} ; \mathrm{P}\}$ coordinates $\left(\mathrm{n}=5 ; \mathrm{R}^{2}>0.95 ; \mathrm{F}<0.02\right) ; \boldsymbol{C}$ - the effect of different sufite concentrations on sulfite reductase activity $(M \pm m, n=5) ; \boldsymbol{D}$ - linearization of concentration curves, which are shown in Fig. 3, $C$, in the Lineweaver-Burk plot, where $V$ is rate of sulfite reductase reaction and $S$ is substrate concentration $\left(n=5 ; R^{2}>0.95 ; F<0.005\right)$

Рис. 3. Кінетичніпараметрисульфітредуктази безклітиннихекстрактів D. pigerVib-7 i Desulfomicrobiumsp. Rod-9: $\boldsymbol{A}$ - динаміка утворення продукту (M $\pm \mathrm{m}, \mathrm{n}=5)$; $\boldsymbol{B}$ - лінеаризація кривих утворення продукту у $\{\mathrm{P} / \mathrm{t} ; \mathrm{P}\}$ координатах $\left(\mathrm{n}=5 ; \mathrm{R}^{2}>0.95 ; \mathrm{F}<0.02\right) ; \boldsymbol{C}$ - вплив різної концентрації сульфріту на активність сульфрітредуктази ( $\mathrm{M} \pm \mathrm{m}, \mathrm{n}=5)$; $\boldsymbol{D}$ - лінеаризація концентраційних кривих, які показані на рис. 3, C, у координатах Лайнуівера-Берка, де $V$ - швидкість реакції, каталізованої сульфітредуктазою, $S$ - концентрація субстрату $\left(n=5 ; R^{2}>0.95 ; F<0.005\right)$

Amount of product of sulfite reductase reaction in the $D$. piger Vib-7 was higher compared to the Desulfomicrobium sp. Rod-9 in the entire range of time factor. The basic kinetic properties of the reaction in the cell-free extracts of the sulfate-reducing bacteria were calculated by linearization of the data in the $\{\mathrm{P} / \mathrm{t}$; P $\}$ coordinates (Fig. 3, B, Table 3). 
Table 3. Kinetic parameters of hydrogen uptake in cell-free extracts of Desulfovibrio piger Vib-7 and Desulfomicrobium sp. Rod-9

Таблиця 3. Кінетичні параметри поглинання гідрогену безклітинними екстрактами Desulfovibrio piger Vib-7 i Desulfomicrobium sp. Rod-9

\begin{tabular}{l|c|c|}
\multirow{2}{*}{\multicolumn{1}{c}{ Kinetic parameters }} & \multicolumn{2}{c}{ Sulfate-reducing bacteria } \\
\cline { 2 - 3 } & Desulfovibrio piger Vib-7 & Desulfomicrobium sp. Rod-9 \\
\hline$V_{0}\left(\mu \mathrm{mol} / \mathrm{min} \times \mathrm{mg}^{-1}\right.$ protein $)$ & $0.351 \pm 0.033$ & $0.138 \pm 0.012^{* * *}$ \\
\hline$P_{\max }\left(\mu \mathrm{mol} / \mathrm{mg}^{*}\right.$ protein $)$ & $2.042 \pm 0.211$ & $1.598 \pm 0.143^{* *}$ \\
$\tau(\min )$ & $5.827 \pm 0.562$ & $11.614 \pm 1.036^{* * *}$
\end{tabular}

Comment: $V_{0}$ is initial (instantaneous) reaction rate; $P_{\max }$ is maximum amount (plateau) of the product of reaction; $\tau$ is the reaction time (half saturation period). Significance of the values $M \pm m, n=5$; ${ }^{* *} \mathrm{P}<0.01 ;{ }^{* * *} \mathrm{P}<0.001$, compared to the Desulfovibrio piger Vib-7 strain.

Примітка: $V_{0}$ - початкова (миттєва) швидкість реакції; $P_{\max }$ - максимальна кількість (плато) продукту реакції; $\tau$ - час реакції (період напівнасичення). Достовірність значень $\mathrm{M} \pm \mathrm{m}, \mathrm{n}=5$; ** $\mathrm{P}<0,01$; ${ }^{* \star \star} \mathrm{P}<0,001$, порівняно до штаму Desulfovibrio piger Vib-7.

The kinetic parameters of sulfite reductase in D. piger Vib-7 and Desulfomicrobium sp. Rod-9 cell-free extracts were significantly different. Values of initial (instantaneous) reaction rate $\left(V_{0}\right)$ for sulfite reductase activity in the cell-free extracts of both bacterial strains was calculated by the maximum amount of the product reaction $\left(P_{\max }\right)$. As shown in Table $3, V_{0}$ for sulfite reductase reaction was higher in the cell-free extracts of D. piger Vib-7 $\left(0.351 \pm 0.033 \mu \mathrm{mol} / \mathrm{min} \times \mathrm{mg}^{-1}\right.$ protein) compared to Desulfomicrobium $\mathrm{sp}$. Rod-9 $\left(0.138 \pm 0.012 \mu \mathrm{mol} / \mathrm{min} \times \mathrm{mg}^{-1}\right.$ protein). Based on these data, there is an assumption that the D. piger Vib-7 can consume sulfite much faster in their cells than a Desulfomicrobium sp. Rod-9. Moreover, this hypothetical assumption can be also confirmed by previously obtained data on the accumulation of intermediates and the final products of their metabolism because $D$. piger Vib-7 accumulated trithionate, polythionate and hydrogen sulfide more intensively compared to Desulfomicrobium sp. Rod-9 (see Table 2).

The kinetic analysis of sulfite reductase activity dependence on the substrate concentration was carried out. According to the obtained results, increasing of sulfite concentrations from 0.5 to $5.0 \mathrm{mM}$ causes a monotonic rise of the studied enzyme activity and the activity was maintained on unchanged level (plateau) under substrate concentrations over $5.0 \mathrm{mM}$ (Fig. $3, C$ ). Curves of the dependence $\{1 / \mathrm{V} ; 1 /[\mathrm{S}]\}$ were distinguished by the tangent slope and intersect the vertical axis in one point (Fig. 3, D). The basic kinetic parameters of sulfite reductase activity in $D$. piger Vib-7 and Desulfomicrobium sp. Rod-9 cell-free extracts were identified by linearization of the data in the Lineweaver-Burk plot (Table 4).

The $K_{m}$ values are milimolar concentration ranges which are consistent with similar constants from the literature data [7]. Calculation of the kinetic parameters of sulfite reductase activity indicates that the maximum rate $\left(V_{\max }\right)$ of hydrogen uptake in the cellfree extracts of $D$. piger Vib-7 and Desulfomicrobium sp. Rod-9 was similar to each other. Michaelis constants $\left(K_{m}\right)$ of sulfite reductase for both bacterial strains were also approximately similar: $3.53 \pm 0.334$ and $3.86 \pm 0.341 \mathrm{mM}$ for $D$. piger Vib-7 and Desulfomicrobium sp. Rod-9, respectively.

ISSN 1996-4536 (print) • ISSN 2311-0783 (on-line) • Біологічні Студії / Studia Biologica • 2014 • Том 8/№2 • C. 101-112 
Table 4. Kinetic parameters of sulfite reductase activity dependence on sulfite concentration in the incubation medium

Таблиця 4. Кінетичні параметри сульфітредуктази залежно від концентрації сульфіту в інкубаційному середовищі

\begin{tabular}{|l|c|c|}
\multirow{2}{*}{ Kinetic parameters } & \multicolumn{2}{|c}{ Sulfate-reducing bacteria } \\
\cline { 2 - 3 } & Desulfovibrio piger Vib-7 & Desulfomicrobium sp. Rod-9 \\
\hline$V_{\max }\left(\mu \mathrm{mol} / \mathrm{min}^{*} \mathrm{mg}^{-1}\right.$ protein $)$ & $0.067 \pm 0.0053$ & $0.045 \pm 0.0039$ \\
$K_{m}(\mathrm{mM})$ & $3.53 \pm 0.334$ & $3.86 \pm 0.341$
\end{tabular}

Comment: $V_{\max }$ is maximum rate of the enzyme reaction; $K_{m}$ is Michaelis constant which was determined by sulfite. Significance of the values $\mathrm{M} \pm \mathrm{m}, \mathrm{n}=5$.

Примітка: $V_{\max }$ - максимальна швидкість ензиматичної реакції; $K_{m}$ - константа Міхаеліса, визначена за сульфітом. Достовірність значень $\mathrm{M} \pm \mathrm{m}, \mathrm{n}=5$.

The obtained parameters of sulfite reductase reaction in the cell-free extracts of D. piger Vib-7 are consistent to Michaelis constant $\left(K_{m} 3.6 \times 10^{-3} \mathrm{M}\right)$ defined previously by Kobayashi et al. for sulfite reduction in the extract of Desulfovibrio vulgaris. The authors have also investigated the biochemical characteristics of sulfite reductase from sulfatereducing bacterium, $D$. vulgaris. Trithionate, thiosulfate, and sulfide were detected even in the early phase of sulfite reduction and the amount of each compound did not decrease during the reaction or after hydrogen uptake ceasing. Kobayashi et al. have shown that trithionate and thiosulfate are not reduced by the enzyme, indicating that these three compounds are produced by sulfite reductase. At high concentrations of sulfite and low concentrations of methyl viologen, trithionate was the dominant product. Under the opposite conditions, the accumulation of relatively large amounts of sulfide or thiosulfate was observed. On the basis of these findings, a mechanism of reaction was proposed, taking into consideration labile intermediates, presumably sulfoxylate and elemental sulfur, which accept electrons from reduced methyl viologen to form sulfur and sulfide or react with sulfite to produce trithionate and thiosulfate, respectively [7].

\section{CONCLUSIONS}

Based on the obtained studies results and according to the kinetic parameters of sulfite reductase reaction for both bacterial strains, we have concluded that the activity of sulfite reductase, $V_{0}$ and $V_{\max }$ were significantly higher in the $D$. piger Vib-7 cells than Desulfomicrobium sp. Rod-9. However, Michaelis constants $\left(K_{m}\right)$ of the sulfite reductase were similar and designated $3.53 \pm 0.334$ and $3.86 \pm 0.341 \mathrm{mM}$ for $D$. piger Vib-7 and Desulfomicrobium sp. Rod-9, respectively. The maximum sulfite reductase activity for both strains has been determined at $+30 \ldots 35^{\circ} \mathrm{C}$ and at $\mathrm{pH} 7.0$. The intermediate products of the bacterial metabolism (thiosulfate, trithionate, and polythionate) were determinated in the cell-free extracts for both strains. The spectral analysis of the purified sulfite reductase from the cell-free extracts of $D$. piger Vib-7 and Desulfomicrobium sp. Rod-9 was carried out. The absorption maxima were 284, 391, 412, 583, and $630 \mathrm{~nm}$ as well as 287, 393, 545 , and $581 \mathrm{~nm}$ for sulfite reductase of $D$. piger and Desulfomicrobium sp. Rod-9, respectively. The kinetic parameters of sulfite reductase reaction depended on the substrate concentration. According to the obtained results, increasing of sulfite concentrations from 0.5 to $5.0 \mathrm{mM}$ causes a monotonic rise of studied enzyme activity and the activity was maintained on an unchanged level (plateau) under substrate concentrations over $5.0 \mathrm{mM}$.

ISSN 1996-4536 (print) • ISSN 2311-0783 (on-line) • Біологічні Студії / Studia Biologica • 2014 • Том 8/№2 • С. 101-112 
According to these data, D. piger Vib-7 strain can be more dangerous and have some pathogenic significance in inflammatory bowel diseases development, consuming sulfite and producing hydrogen sulfide at a higher rate. The studies of the physiological and biochemical properties of the intestinal sulfate-reducing bacteria, the process of the dissimilatory sulfate reduction, in particular participation of sulfite reductase in this process, the activity and kinetic properties of this enzyme in the D. piger Vib-7 and Desulfomicrobium sp. Rod-9 bacterial strains, their production of hydrogen sulfide in detail can be perspective for clarification of the etiological role of these bacteria in the development of various diseases. The data on the concentration of hydrogen sulfide, produced by the isolates is supposed to help in establishing and assessing a toxicity effect of these compounds on the epithelial cells of the human and animal intestine. These studies might help in predicting the development of diseases of the gastrointestinal tract, by providing further details on the etiology of bowel diseases which are very important for the clinical diagnosis of these disease types.

\section{Acknowledgements}

This study was supported by University of Veterinary and Pharmaceutical Sciences Brno (project OPVK „Pharmaco-toxicological evaluation of newly synthesized (isolated) compounds as an integration tool for pre-clinical disciplines at VFU Brno" CZ.1.07/2.3.00/30.0053).

1. Bailey N.T.J. Statistical Methods in Biology. Cambridge University Press, 1995; 255 p.

2. Barton L.L., Hamilton W.A. Sulphate-reducing Bacteria. Environmental and Engineered. Cambridge University Press, 2007; 553 p.

3. Cummings J.H., Macfarlane G.T., Macfarlane S. Intestinal Bacteria and Ulcerative Colitis. Curr. Issues Intest. Microbiol, 2003; 4: 9-20.

4. Gibson G.R., Cummings J.H., Macfarlane G.T. Growth and activities of sulphate-reducing bacteria in gut contents of health subjects and patients with ulcerative colitis. FEMS Microbiol. Ecol, 1991; 86: 103-112.

5. Keleti T. Basic Enzyme Kinetics. Akademiai Kiado, 1988; 422 p.

6. Kobayashi K., Takahashi E., Ishimoto M. Biochemical studies on sulfate-reducing bacteria. XI. Purification and some properties of sulfite reductase, desulfoviridin. J. Biochem, 1972; 72(4): 879-887.

7. Kobayashi K., Seki Y. and Ishimoto M. Biochemical Studies on Sulfate-reducing Bacteria XIII. Sulfite Reductase from Desulfovibrio vulgaris - Mechanism of Trithionate, Thiosulfate, and Sulfide Formation and Enzymatic Properties. J. Biochem, 1974. 75(3): 519-529.

8. Kosterin S.A., Burchynskaya N.F. The method for determining the characteristics kinetics of the $\mathrm{Ca}^{2+}$-transport systems subcells structures of smooth muscles. Ukrainian Biochem. $\mathbf{J}$, 1987; 59(2): 66-69.

9. Kushkevych I.V. Sulfate-reducing bacteria of the human intestine. I. Dissimilatory sulfate reduction. Sci. Int. J. Biological Studies/Studia Biologica. 2012; 6(1): 149-180.

10. Kushkevych I.V. Sulfate-reducing bacteria of the human intestine. II. The role in the diseases development. Sci. Int. J. Biological Studies/Studia Biologica. 2012; 6(2): 221-250.

11. Kushkevych I.V. Identification of sulfate-reducing bacteria strains of human large intestine. Sci. Int. J. Biological Studies/Studia Biologica, 2013; 7(3): 115-124.

12. Kushkevych I.V., Bartos M., Bartosova L. Sequence analysis of the 16S rRNA gene of sulfate-reducing bacteria isolated from human intestine. Int. J. Curr. Microbiol. Appl. Sci, 2014; 3(2): 239-248.

ISSN 1996-4536 (print) • ISSN 2311-0783 (on-line) • Біологічні Студії / Studia Biologica • 2014 • Том 8/№2 • C. 101-112 
13. Lee J.P., Yi C.S., LeGall J., and Peck H.D.Jr. Isolation of a New Pigment, Desulforubidin, from Desulfovibrio desulfuricans (Norway Strain) and Its Role in Sulfite Reduction. J. Bacteriol, 1973; 115(1): 453-455.

14. Lee J.P., LeGall J., Peck H.D.Jr. Isolation of Assimilatory- and Dissimilatory-Type Sulfite Reductases from Desulfovibrio vulgaris. J. Bacteriol, 1973; 115(2): 529-542.

15. Lowry O.H., Rosebrough N.J, Farr A.L., Randall R.J. Protein determination with the Folin phenol reagent. J. Biol. Chem, 1951; 193: 265-275.

16. Morse R., Gibson G.R., Collins M.D. Secondary structure analysis of the dissimilatory sulphite reductase in Desulfovibrio desulfuricans. Lett. Appl. Microbiol, 2000; 30: 375-378.

17. Peck H.D., Van Beeumen J., and LeGall J. Biochemistry of Dissimilatory Sulphate Reduction and Discussion. Phil. Trans. R. Soc. Lond. B, 1982; 298: 443-466.

18. Steuber J. and Kroneck P.M.H. Desulfoviridin, the dissimilatory sul.te reductase from Desulfovibrio desulfuricans (Essex): new structural and functional aspects of the membranous enzyme. Inorganica Chimica Acta, 1998; 276: 52-57.

19. Steuber J., Arendsen A.F., Hagen W.R. and Kroneck P.M.H. Molecular properties of the dissimilatory sulfite reductase from Desulfovibrio desulfuricans (Essex) and comparison with the enzyme from Desulfovibrio vulgaris (Hildenborough). Eur. J. Bioch, 1995; 233: 873-879.

20. Steuber J., Cypionka H. and Kroneck P.M.H. Mechanism of dissimilatory sulfite reduction by Desulfovibrio desulfuricans. Purification of a membrane-bound sulfite reductase and coupling with cytochrome $c_{3}$ and hydrogenase. Arch. Microbiol, 1994; 162: 255-260.

\title{
ДИСИМІЛЯЦІЙНА СУЛЬФІТРЕДУКТАЗА БЕЗКЛІТИННИХ ЕКСТРАКТІВ КИШКОВИХ СУЛЬФАТВІДНОВЛЮВАЛЬНИХ БАКТЕРІЙ
}

\author{
Іван Кушкевич ${ }^{1,2}$, Роман Фафула ${ }^{3}$ \\ ${ }^{1}$ /нститут біології тварин НААН України, вул. В. Стуса, 38, Львів 79034, Україна \\ ${ }^{2}$ Університет ветеринарних і фрармацевтичних наук Брно \\ Palackeho, 1/3, CZ-61242 Брно, Чеська Республіка \\ e-mail: ivan.kushkevych@gmail.com \\ ${ }^{3}$ Львівський національний медичний університет імені Данила Галицького \\ вул. Пекарська, 69, Львів 79010, Україна
}

Досліджено активність дисиміляційної сульфітредуктази у різних фрракціях сульфатвідновлювальних бактерій Desulfovibrio piger Vib-7 та Desulfomicrobium sp. Rod-9, ізольованих із кишечника людини. Сульфітредуктазу, важливий фермент процесу метаболізму сірки цих бактерій, солюбілізовано з мембранної фракції. Найвища активність фрерменту виявлена у безклітинних екстрактах бактеріальних штамів $\left(0,032 \pm 0,0026\right.$ і 0,028 $\pm 0,0022 \mathrm{U} \times \mathrm{mg}^{-1}$ білка для $D$. piger Vib-7 та Desulfomicrobium sp. Rod-9, відповідно), порівняно з іншими фрракціями. Визначено оптимальну температуру $\left(+30 \ldots 35^{\circ} \mathrm{C}\right)$ і $\mathrm{pH} 7,0$ для реакції сульфрітредуктази в екстрактах обох бактеріальних штамів. Проведено спектральний аналіз очищеної сульфітредуктази з безклітинних екстрактів. Максимуми поглинання були 284, 391, 412, 583, 630 нм, а також 287, 393, 545, 581 нм для сульфітредуктази D. piger Vib-7 та Desulfomicrobium sp. Rod-9, відповідно. Встановлено, що активність сульфітредуктази, початкова (миттєва) швидкість $\left(V_{0}\right)$ і максимальна швидкість $\left(V_{\max }\right)$ реакції сульфітредуктази вища у клітин D. piger Vib-7, ніж у Desulfomicrobium sp. Rod-9. Проте константи Miхаеліса $\left(K_{m}\right)$ для активності фрерменту були близькими для обох штамів бактерій. Дослідження активності сульфітредуктази, кінетичні властивості цього фрерменту у штамів кишкових сульфатвідновлювальних бактерій, а також детальне вивчення

ISSN 1996-4536 (print) • ISSN 2311-0783 (on-line) • Біологічні Студії / Studia Biologica • 2014 • Том 8/№2 • С. 101-112 
акумуляції ними гідроген сульфіду, перспективні для з'ясування етіологічної ролі цих бактерій у розвитку запальних захворювань кишечника людини і тварин.

Ключові слова: сульфатвідновлювальні бактерії, сульфітредуктаза, мікробіоценоз кишечника, запальні кишкові захворювання, виразкові коліти.

\title{
ДИССИМИЛЯЦИОННАЯ СУЛЬФИТРЕДУКТАЗА БЕСКЛЕТОЧНЫХ ЭКСТРАКТОВ КИШЕЧНЫХ СУЛЬФАТВОССТАНАВЛИВАЮЩИХ БАКТЕРИЙ
}

\author{
Иван Кушкевич ${ }^{1,2}$, Роман Фафула ${ }^{3}$ \\ ${ }^{1}$ Институт биологии животных НААН Украины, ул. В. Стуса, 38, Львов 79034, Украина \\ ${ }^{2}$ Университет ветеринарных и фрармацевтических наук Брно \\ Palackeho, 1/3, CZ-61242 Брно, Чешская Республика \\ e-mail: ivan.kushkevych@gmail.com
}

${ }^{3}$ Львовский национальный медицинский университет имени Даниила Галицкого ул. Пекарская, 69, Львов 79010, Украина

Исследована активность диссимиляционной сульфитредуктазы в различных клеточных фрракциях сульфатвосстанавливающих бактерий Desulfovibrio piger Vib-7 и Desulfomicrobium sp. Rod-9, изолированных из кишечника человека. Сульфитредуктаза, важный фермент процесса метаболизма серы сульфатвосстанавливающих бактерий, была солюбилизована из мембранной фракции. Наивысшая активность фрермента обнаружена в бесклеточных экстрактах бактериальных штаммов $\left(0,032 \pm 0,0026\right.$ и 0,028 $\pm 0,0022 \mathrm{U} \times \mathrm{mg}^{-1}$ белка для D. piger Vib-7 и Desulfomicrobium sp. Rod-9, соответственно) по сравнению с другими фракциями. Определены оптимальные значения температуры $\left(+30 \ldots 35^{\circ} \mathrm{C}\right)$ и $\mathrm{pH} 7,0$ для реакции сульфитредуктазы в экстрактах обоих бактериальных штаммов. Проведен спектральный анализ очищенной сульфитредуктазы из бесклеточных экстрактов. Максимумы поглощения были 284, 391, 412, 583, 630 нм, а также 287, 393, 545, 581 нм для сульфитредуктазы D. piger Vib-7 и Desulfomicrobium sp. Rod-9, соответственно. Проведен анализ кинетических свойств этого фермента у исследуемых бактерий. Установлено, что активность сульфитредуктазы, начальная (мгновенная) скорость $\left(V_{0}\right)$ и максимальная скорость $\left(V_{\max }\right)$ реакции сульфитредуктазы выше у клеток $D$. piger Vib-7, чем в Desulfomicrobium sp. Rod-9. Однако константы Михаэлиса $\left(K_{m}\right)$ для активности фермента были близкими для обоих штаммов бактерий. Исследование активности сульфитредуктазы, кинетические свойства этого фрермента у штаммов кишечных сульфатвосстанавливающих бактерий, а также изучение аккумуляции ими гидроген сульфида, перспективны для выяснения этиологической роли этих бактерий в развитии воспалительных заболеваний кишечника человека и животных.

Ключевые слова: сульфатвосстанавливающие бактерии, сульфитредуктаза, микробиоценоз кишечника, воспалительные кишечные заболевания, язвенные колиты.

Одержано: 25.04.2014

ISSN 1996-4536 (print) • ISSN 2311-0783 (on-line) • Біологічні Студії / Studia Biologica • 2014 • Том 8/№2 • C. 101-112 